\title{
Effect of alternate wetting and drying (AWD) irrigation for Boro rice cultivation in Bangladesh
}

\author{
Md. Redwanur Rahman, Sheikh Helena Bulbul \\ Institute of Environmental Science, University of Rajshahi, Rajshahi, Bangladesh \\ Email address: \\ redwan_rahman@1ycos.com (Md. R. Rahman), hbsplendid07@gmail.com (S. H. Bulbul)
}

To cite this article:

Md. Redwanur Rahman, Sheikh Helena Bulbul. Effect of Alternate Wetting and Drying (AWD) Irrigation for Boro Rice Cultivation in Bangladesh. Agriculture, Forestry and Fisheries. Vol. 3, No. 2, 2014, pp. 86-92. doi: 10.11648/j.aff.20140302.16

\begin{abstract}
A field experiment was conducted at the Bangladesh Rice Research Institute to find out possible effects of alternate wetting and drying irrigation (AWDI) on the yield, water use and water use efficiency (WUE) of Boro rice. The experimental plots were laid out with 2 factors RCBD combining two modern varieties of rice viz., BRRI dhan 29 and BRRI hybrid2, which received four irrigation treatments randomly and was replicated thrice. The treatments ranged from continuous submergence $\left(T_{1}\right)$ of the field to a number of delayed irrigations $\left(T_{2}, T_{3}\right.$ and $\left.T_{4}\right)$ denoting application of $5 \mathrm{~cm}$ irrigation water when water level in the perforated PVC pipe fell 15, 20 and $25 \mathrm{~cm}$ below ground level (G.L.), respectively. The study revealed that treatment $T_{1}$ attributed by the highest total water use $(122.2 \mathrm{~cm})$ and the lowest WUE $(84.34 \mathrm{~kg} / \mathrm{ha} / \mathrm{cm})$ produced the lowest grain yield (4.71t/ha). Treatment $T_{2}$, on the contrary, gave the highest yield $(5.69 \mathrm{t} / \mathrm{ha})$ and consequently the second highest WUE $(85.55 \mathrm{~kg} / \mathrm{ha} / \mathrm{cm})$ indicating quite a large water saving $(15 \mathrm{~cm})$ compared to treatment $\mathrm{T}_{1}$. The yields in treatments $\mathrm{T}_{3}(5.45 \mathrm{t} / \mathrm{ha})$ and $\mathrm{T}_{4}(5.27 \mathrm{t} / \mathrm{ha})$ were significantly lower at $1 \%$ level of significance compared to that of treatment $T_{1}$. Significant effect was found either for the treatment or for the varieties on the number of effective and total tillers hill -1, plant height, number of effective tillers hill-1, grain yield, straw yield, biological yield and harvest index.
\end{abstract}

Keywords: Alternate Wetting and Drying Irrigation, Boro Rice, Yield, Water Use Efficiency

\section{Introduction}

In agriculture sector rice is the only major grain crop that is grown almost exclusively as food needs mush water to produce. Rice grown under traditional practices in the Asian tropics and subtropics requires between $700-1500 \mathrm{~mm}$ of water per cropping season depending on soil texture [1]. However, this conventional water management method leads to a high amount of surface runoff, seepage, and percolation that can account for between $50-80 \%$ of the total water input [2].

The interactions between water use for rice cultivation, surface water and groundwater resources are often very close-such that active cross-sector dialogue and integrated vision are also needed to promote sustainable water use.

Sustainability is often referred to as a process which leads to better relationships between humans and the natural environment and between themselves. [3] emphasizes this relationship and reinforces that Sustainability is the doctrine that economic growth and development must take place, and be maintained over time, within the limits set by ecology in the broadest sense by the interrelations of human beings and their works, the biosphere and the physical and chemical laws that govern it. It follows that environmental protection and economic development are complementary rather than antagonistic processes, (Scientific American: September, 1989). The outcome of this interrelated process is balanced development. This is supported by the Florida Centre for Community Design and Research (2010) which states that Sustainability is the optimal balance of natural, economic and social systems overtimes.

The sustainability concept argues for a holistic and balanced approach to life where economic prosperity, nature conservation and social justice are given equal weight in any long term strategies of [4]. New definitions of sustainability are constantly emerging, however they all share common aspects. The Research Group on the Global Futures provides an array of definitions for sustainability but concludes that most definitions have three aspects in common. These are living within limits; understanding the interconnections between the economy, society and the environment and equitable distribution of resources and opportunities (Research Group on Global Futures 2005). [5] see sustainability as a matter of making adjustments to present human activities, to sustain twentieth 
century natural resources largely unchanged and unchallenged into the twenty-first century. Hence, the main feature of sustainability is the direct practical changes that it requires. Sustainability is very important for this research as it deals with the way the sustainability concepts in terms of water use for rice cultivation are being transferred and reinforced in young people, researcher, farmers, and policy makers through the educational system.

Many researchers indicate that rice is the major consumer of irrigation water in Bangladesh. It is grown under two distinct water regions, continuous standing and alternate wetting. The conventional method of rice planting requires continuous pond water on the field, which is possible where irrigation water is abundant and cheap. In this method irrigation water is used for evapotranspiration (ET) and seepage-percolation $(\mathrm{S} \& \mathrm{P})$. But in reality, only ET is the true water requirement for crop growth and $\mathrm{S} \& \mathrm{P}$ are the unavoidable losses. However, rice can be grown under alternate wetting and drying conditions with necessarily sacrificing yields and adoption of such practices may allow savings of costly water. Alternate Wetting and Drying (AWD) involves technology that tackles water scarcity in irrigated rice cultivation and has the potential to contribute to a more sustainable and effective water and energy use. This AWD tool is a single device designed to observe water level in rice field for deciding the time of irrigation. It involves installation of a perforated pipe (preferably PVC) in rice field to allow observation of water level. In one part, such pipe of $10 \mathrm{~cm}$ diameter and $30 \mathrm{~cm}$ long is installed having $10 \mathrm{~cm}$ above and $20 \mathrm{~cm}$ below the ground surface.

By applying AWD, farmers or pump-owners are able to save 15 to $30 \%$ of their irrigation water. Water productivity, i.e. the volume of irrigation water required to produce a certain amount of rice, increases compared to conventional cultivation [6], [7]. To identify the sustainable water management for boro rice cultivation by practicing alternate wetting and drying (AWD) was the core objective of this study. More specifically, the objective could be outlined as to find out, from a number of AWDI irrigation treatments, the best one with the highest water use efficiency that would result in an insignificant yield loss and ensure the best use of the available water resources.

\section{Materials and Methods}

The Bangladesh Rice Research Institute (BRRI) Farm of Gazipur was selected as the experimental site. Topography of the land being plain was suitable for check basin irrigation. Individual plots were located inside a close growing rice field so that actual growing condition (reception of the direct and diffused fluxes) prevails in the site. Soil texture of the experimental site was found to be silty loam. The upper root zone of the experimental field was tilled with high puddling intensity. The experimental plots $(4 \times 2.5 \mathrm{~m})$ were laid out with 2 factors RCBD combining two modern varieties of rice (BRRIdhan 29 and BRRI hybrid2) and four irrigation treatments that were replicated thrice. This resulted in a total of 24 plots in the field with 8 plots in a row. Each of the plots was separated by $1 \mathrm{~m}$ of transition zone while each of the replications was demarcated by a buffer zone of $1.5 \mathrm{~m}$ in between. To prevent seepage, polythene sheets were pushed into the edges of the levees along the inner perimeter of all plots. PVC pipes of $4 \mathrm{~cm}$ in diameter and $40 \mathrm{~cm}$ in length were installed in the field keeping $7 \mathrm{~cm}$ above the soil and the remaining $33 \mathrm{~cm}$ which was perforated underneath to measure the depletion of soil water in the field. Irrigation water was applied when depleting water table inside the pipe reached a certain level.

The first treatment $\left(T_{1}\right)$ was continuous submergence ( 1 to $5 \mathrm{~cm}$ standing water) and the remaining three $\left(\mathrm{T}_{2}, \mathrm{~T}_{3}\right.$ and $\left.\mathrm{T}_{4}\right)$ stood for an application of $5 \mathrm{~cm}$ irrigation water when water level in the pipe fell 15, 20 and $25 \mathrm{~cm}$ below the G.L., respectively. Continuous standing water $(5 \mathrm{~cm})$ was maintained in all the plots up to 28 days after transplantation (DAT) to avoid pre-apprehended weed infestation that could be awesome during crop establishment stage. A bowl of 1.5liters was used to irrigate the plots from the buffer zones by throwing water in. The seedlings were transplanted maintaining hill to hill distance of $15 \mathrm{~cm}$ and row to row distance of $25 \mathrm{~cm}$. The first and the last hills were kept at $7.5 \mathrm{~cm}$ away from their nearest levees resulting in 25 hills along the length and 10 hills along the width. Since the grains of BRRI hybrid 2 got ripened earlier than the BRRIdhan 29, the former was harvested (01 May 2008) two weeks earlier than the harvesting date (May 14, 2008) of the latter. Matured plants inside $1 \mathrm{~m}$ square of land were harvested for subsequent analysis. Moisture content of the grains, however, was adjusted to $14 \%$ equivalent moisture content after measuring through digital grain moisture meter for subsequent analysis. Quantitative information related to yield and all the yield contributing characters viz., plant height, effective tillers, length of the panicle, no. of spike lets per panicle, no. of filled and unfilled grains per panicle, 1000 grain weight, grain yield, straw yield, harvest index and water use efficiency of the two varieties (BRRIdhan 29 and BRRI hybrid2) were analyzed to obtain the effect for AWDI on rice production.

\section{Results and Discussions}

Significant consequences of AWDI on the production of Boro rice were observed as given in Tables 1 . The analysis showed that varietal effect on plant height was statistically significant at $1 \%$ probability level. The tallest plant $(107.00 \mathrm{~cm})$ was found in BRRI hybrid2 $\left(\mathrm{V}_{2}\right)$. The shortest plant $(101.95 \mathrm{~cm})$ was found in BRRI dhan $29\left(\mathrm{~V}_{1)}\right.$. Variation in plant height might be due to the differences in the genetic make-up of the varieties. The result is in consistent with findings of [8] who also reported a variable plant height existed among the varieties. The highest number of total tillers hill $^{-1}(10.96)$ was found in BRRI hybrid2 and the lowest number of total tiller was found (10.63) in BRRI dhan29. The variation in number of total tillers hill ${ }^{-1}$ might be due to varietal characteristics. The highest number of 
effective tillers (9.11) was found in BRRI hybrid2 and the lowest number of effective tiller $\operatorname{hill}^{-1}(8.68)$ was found in BRRI dhan29. The highest number of non-effective tillers (1.95) was found in BRRI dhan29 and the lowest number of non-effective tiller hill ${ }^{-1}$ (1.85) was found in BRRI hybrid2. The highest length of panicle $(22.92 \mathrm{~cm})$ was found in BRRI dhan 29. The lowest length of panicle was $(22.80 \mathrm{~cm})$ in BRRI hybrid2. The results showed that the highest grain yield (137.64) was achieved from BRRI hybrid2. The lowest grain yield (118.45) was achieved from BRRI dhan29. The highest number of unfilled grains panicle ${ }^{-1}$ (22.64) was found in BRRIdhan 29. The lowest number of unfilled grains panicle ${ }^{-1}$ was found from BRRI hybrid2. The result showed that the highest weight of 1000- grain (23.65g) was obtained from BRRI hybrid2. The lowest weight of 1000-grain (23.35g) was obtained from BRRIdhan29. Grain yield was statistically significant at $1 \%$ level of probability. The highest grain yield (5.64 t/ha) was achieved from BRRI hybrid2. The lowest grain yield (4.93t/ha) was achieved from BRRIdhan 29. These differences occurred due to variations of genetic make-up among the varieties. The result shows that the highest straw yield $\left(6.70 \mathrm{tha}^{-1}\right)$ was found from BRRI hybrid2. The lowest straw yield $\left(5.83 \mathrm{tha}^{-1}\right)$ was found from BRRI dhan29. The highest yield occurred due to higher plant height, higher total tiller hill ${ }^{-1}$ and lower number non-effective tiller hill ${ }^{-1}$. These results are consistent with those obtained by [9] who reported differences in straw yield among varieties.

The highest biological yield $\left(12.34 \mathrm{tha}^{-1}\right)$ was obtained from BRRI hybrid2 and the lowest one (10.76tha ${ }^{-1}$ ) was obtained from BRRIdhan 29. Maximum harvest index $(45.73 \%)$ was obtained from BRRIdhan 29 and the minimum harvest index $(45.65 \%)$ was obtained from BRRI hybrid2.

The experiment aimed in exploring the possible effects of different irrigation treatments on the production and production related parameters. Different yield contributing characters viz., plant height $(\mathrm{cm})$, number of effective tillers per hill, panicle length $(\mathrm{cm})$, total number of filled grains per panicle, number of unfilled grains per panicle; 1000 seed weight (gm), grain yield (t/ha) and straw yield ( $\mathrm{t} / \mathrm{ha}$ ) for each of the varieties were analyzed. Statistical relationships of the effect of four treatments on the individual yield contributing parameters are given with their detail statistical analysis in Table 2.

Table 1. Varietal (BRRI dhan29 and BRRI hybrid2) Effect on the Yield and Yield Contributing Characters.

\begin{tabular}{|c|c|c|c|c|c|c|c|c|c|c|c|c|}
\hline Variety & $\begin{array}{l}\text { Plant } \\
\text { height } \\
\text { (cm) }\end{array}$ & $\begin{array}{l}\text { Total } \\
\text { tiller } \\
\text { Hill }^{-1} \\
\end{array}$ & $\begin{array}{l}\text { Effective } \\
\text { tiller } \\
\text { Hill }^{-1}\end{array}$ & $\begin{array}{l}\text { Non-effective } \\
{\text { tiller } \text { Hill }^{-1}}^{\text {a }}\end{array}$ & $\begin{array}{l}\text { Panicle } \\
\text { length } \\
\text { (cm) }\end{array}$ & $\begin{array}{l}\text { Filled } \\
\text { grain } \\
\text { panicle }^{-1}\end{array}$ & $\begin{array}{l}\text { Unfilled } \\
\text { grain } \\
\text { panicle }^{-1}\end{array}$ & 1000-GW & $\begin{array}{l}\text { Grain } \\
\text { yield } \\
\left(\mathrm{t} / \mathrm{ha}^{-1}\right)\end{array}$ & $\begin{array}{l}\text { Straw } \\
\text { yield }(t / \\
\left.h^{-1}\right)\end{array}$ & $\begin{array}{l}\text { Biological } \\
\text { yield }\end{array}$ & $\begin{array}{l}\text { Harvest } \\
\text { Index }\end{array}$ \\
\hline$V_{1}$ & 101.95 & 10.63 & 8.68 & 1.95 & 22.92 & 118.45 & 22.64 & 23.35 & 4.93 & 5.83 & 10.76 & 45.73 \\
\hline$V_{2}$ & 107.00 & 10.96 & 9.11 & 1.85 & 22.80 & 137.64 & 20.49 & 23.65 & 5.64 & 6.70 & 12.34 & 45.65 \\
\hline LSD & 0.369 & 0.106 & 0.072 & 0.094 & 0.348 & 0.926 & 0.354 & 0.176 & 0.047 & 0.047 & 0.066 & 0.319 \\
\hline $\begin{array}{l}\text { Level of } \\
\text { sig }\end{array}$ & $* *$ & NS & $* *$ & NS & NS & $* *$ & $* *$ & NS & $* *$ & $* *$ & $* *$ & NS \\
\hline
\end{tabular}

In a column figures with same letter or without letter do not differ significantly whereas figures with dissimilar letter differ significantly (as per DMRT), $\mathrm{V}_{1}$ $=$ BRRIdhan $29, \mathrm{~V}_{2}=$ BRRI hybrid $2, \mathrm{NS}=$ Not Significant, $*=$ Significant at $5 \%$ level of probability, $* *=$ Significant at $1 \%$ level of probability.

Table 2. Effect of Different Irrigation Treatments on the Yield and Yield Contributing Characters.

\begin{tabular}{|c|c|c|c|c|c|c|c|c|c|c|c|c|}
\hline Treatment & $\begin{array}{l}\text { Plant } \\
\text { height }(\mathrm{cm})\end{array}$ & $\begin{array}{l}\text { Total } \\
\text { tiller } \\
\text { Hill }^{-1}\end{array}$ & $\begin{array}{l}\text { Effective } \\
\text { tiller } \\
\text { Hill }^{-1}\end{array}$ & 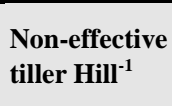 & $\begin{array}{l}\text { Panicle } \\
\text { length } \\
(\mathrm{cm})\end{array}$ & $\begin{array}{l}\text { Filled } \\
\text { grain } \\
\text { panicle }^{-1}\end{array}$ & $\begin{array}{l}\text { Unfilled } \\
\text { grain } \\
\text { panicle }^{-1}\end{array}$ & 1000-GW & $\begin{array}{l}\text { Grain } \\
\text { yield } \\
\left(t_{/ h a}^{-1}\right)\end{array}$ & $\begin{array}{l}\text { Straw } \\
\text { yield } \\
\left(\mathrm{t}^{\prime} / \mathrm{ha}^{-1}\right)\end{array}$ & $\begin{array}{l}\text { Biological } \\
\text { yield }\end{array}$ & $\begin{array}{l}\text { Harvest } \\
\text { Index }\end{array}$ \\
\hline $\mathrm{T}_{1}$ & $103.43 b$ & $10.40 \mathrm{~b}$ & $8.06 \mathrm{c}$ & $2.34 a$ & 23.41 & $119.32 \mathrm{c}$ & $26.80 \mathrm{a}$ & $23.07 \mathrm{~b}$ & $4.71 \mathrm{c}$ & $6.12 b$ & $10.83 \mathrm{c}$ & $43.61 b$ \\
\hline $\mathrm{T}_{2}$ & $105.25 \mathrm{ab}$ & $12.14 \mathrm{a}$ & $11.06 \mathrm{a}$ & $1.08 \mathrm{~b}$ & 22.89 & $141.94 \mathrm{a}$ & $14.07 \mathrm{c}$ & $24.48 \mathrm{a}$ & $5.69 a$ & $6.57 \mathrm{a}$ & $12.26 \mathrm{a}$ & $46.33 a$ \\
\hline $\mathrm{T}_{3}$ & $103.45 b$ & $10.86 \mathrm{~b}$ & $8.67 b$ & $2.19 a$ & 21.72 & $127.38 \mathrm{~b}$ & $23.04 b$ & $22.91 \mathrm{~b}$ & $5.45 b$ & $6.16 b$ & $11.61 \mathrm{~b}$ & $46.96 \mathrm{a}$ \\
\hline $\mathrm{T}_{4}$ & $105.78 \mathrm{a}$ & $9.78 \mathrm{c}$ & $7.78 \mathrm{c}$ & $2.00 \mathrm{a}$ & 23.43 & $123.57 \mathrm{bc}$ & $22.36 b$ & $23.53 b$ & $5.27 \mathrm{~b}$ & $6.22 b$ & $11.49 \mathrm{~b}$ & $45.86 a$ \\
\hline LSD & 0.738 & 0.212 & 0.145 & 0.187 & 0.696 & 1.852 & 0.707 & 0.352 & 0.095 & 0.093 & 0.132 & 0.637 \\
\hline $\begin{array}{l}\text { Level of } \\
\text { sig }\end{array}$ & $*$ & $* *$ & $* *$ & $* *$ & NS & $* *$ & $* *$ & $* *$ & $* *$ & $* *$ & $* *$ & $* *$ \\
\hline
\end{tabular}

In a column figures with same letter or without letter do not differ significantly whereas figures with dissimilar letter differ significantly (as per DMRT), $\mathrm{T}_{1}$ $=$ Continuous Standing water, $\mathrm{T}_{2}=$ Irrigation when water is $15 \mathrm{~cm}$ below from the soil surface, $\mathrm{T}_{3}=$ Irrigation when water is $20 \mathrm{~cm}$ below from the soil surface, $\mathrm{T}_{4}=$ Irrigation when water is $25 \mathrm{~cm}$ below from the soil surface, NS = Not Significant, $*=$ Significant at $5 \%$ level of probability, $* *=$ Significant at $1 \%$ level of probability

The analysis showed that the irrigation treatments had significant effect on plant height at $5 \%$ level of probability. The highest plant height $(105.78 \mathrm{~cm})$ was obtained in treatment $\mathrm{T}_{4}$ (irrigation when water is $25 \mathrm{~cm}$ below from the soil surface) and the lowest $(103.45 \mathrm{~cm})$ in Treatment $T_{1}$ (continuous flooding). This result is in agreement with the findings of [10] who reported that treatment having continuous flooding could not improved plant height. The highest number of effective tillers per hill (11.06) was found in treatment $T_{2}$ followed by treatment $T_{3}(8.67)$ and treatment $\mathrm{T}_{1}$ (8.06). The lowest number of effective tiller per hill (7.78) was found in treatment $\mathrm{T}_{4}$.

It was found that the highest number of filled grains (141.94) per panicle was obtained in treatment $T_{2}$ (irrigation when water is below $15 \mathrm{~cm}$ from the soil surface) followed by treatments $\mathrm{T}_{3}$ (Irrigation when water is $20 \mathrm{~cm}$ below from 
the soil surface) and $\mathrm{T}_{4}$ (Irrigation when water is $25 \mathrm{~cm}$ below from the soil surface). The lowest number of filled grains per panicle (119.32) was found for treatment $T_{1}$. Thus the result showed that applying irrigation water in rice field when water level goes 15 to $25 \mathrm{~cm}$ below G.L does not really reduce the total number of filled grains compared to that nursed with $5 \mathrm{~cm}$ standing water. However, treatment $\mathrm{T}_{1}$ (continuous standing water) decreased the number of filled grains. The highest grain yield $(5.69 \mathrm{t} / \mathrm{ha})$ was obtained from treatment $\mathrm{T}_{2}$ (irrigation when water is below $15 \mathrm{~cm}$ from the soil surface) and the lowest yield grain (4.71t/ha) was obtained from treatment $\mathrm{T}_{1}$ (continuous standing water). The results shows that the grain yield did not decreased when plants suffered little water stress. The second highest yield grain $\left(5.45 \mathrm{t} / \mathrm{ha}\right.$ ) was found in the treatment $\mathrm{T}_{3}$ (when irrigation is $20 \mathrm{~cm}$ below from the soil surface). The maximum straw yield $(6.57 \mathrm{t} / \mathrm{ha})$ was found from the treatment $T_{1}$. The minimum straw yield $(6.12 \mathrm{t} / \mathrm{ha})$ was found from treatment $T_{1}$. The irrigation treatments and of the experiment did not have any significant effect on the harvest index either at $1 \%$ or $5 \%$ level of probability. The highest value of harvest index $(46.96 \%)$ was found for the treatment $\mathrm{T}_{3}$ and the minimum for the $\mathrm{T}_{1}(43.61 \%)$.

Effect of the interaction between the varieties and the treatments was also found to be statistically significant at $1 \%$ level of probability table 3 . The tallest plant height $(109.17 \mathrm{~cm})$ was found for the interaction $\mathrm{V}_{2} \times \mathrm{T}_{2}\left(\mathrm{~V}_{2}=\mathrm{BRRI}\right.$ hybrid2, $T_{2}=$ Irrigation when water is $15 \mathrm{~cm}$ below from the soil surface). The interaction effect (variety $\times$ Irrigation) had any effect on the panicle length of the varieties.

The cause of the non significant output of the panicle length might have occurred due to insufficient photosynthesis from the less vigorous crop canopy and reduced leaf area of BRRIdhan 29 and BRRI hybrid2. The interaction effect of the varieties and treatments also came significant at $5 \%$ level of probability. The highest number of filled grains (145.65) was, however, marked for the interaction $\left(\mathrm{V}_{2} \times \mathrm{T}_{2}\right)$ and the lowest number of filled grains (95.50) was obtained from $\mathrm{V}_{1} \mathrm{~T}_{1}$. The highest 1000 grain weight (24.80) was obtained for the interactions $\left(\mathrm{V}_{2} \times \mathrm{T}_{2}\right)$ and the lowest 1000 grain weight (22.80) was obtained for the $\mathrm{V}_{2} \times \mathrm{T}_{3}$. The study raveled that the varieties $\mathrm{V}_{1}$ and $\mathrm{V}_{2}$ and interaction effect between variety $\times$ treatments produced statistically insignificant variation in 1000 grain weight among themselves. Thus, it was clear from the interaction effect that AWDI method of irrigation treatments did not reduced the 1000 grain weight as irrigation delayed. The interaction between the varieties and treatments also produced significant results for grain yield at the $5 \%$ level of probability. The highest grain yield of BRRI hybrid2 (6.28 $\mathrm{t} / \mathrm{ha}$ ) was obtained for the interaction $\left(\mathrm{V}_{2} \times \mathrm{T}_{2}\right)$ and the lowest grain yield $(4.18 \mathrm{t} / \mathrm{ha})$ was obtained from the interaction $\left(\mathrm{V}_{1} \times \mathrm{T}_{1}\right)$. The interaction between the varieties and treatments also produced significant straw yield at the $1 \%$ level of probability. The highest straw yield (7.06 t/ha) was obtained for the interaction $\left(\mathrm{V}_{2} \times \mathrm{T}_{2}\right)$ and lowest straw yield $(5.26 \mathrm{t} / \mathrm{ha})$ was obtained for the interaction $\left(\mathrm{V}_{1} \times \mathrm{T}_{1}\right)$. Interaction effect of the variety and the treatments were found insignificant either at the $1 \%$ or $5 \%$ level of significant. The highest harvest index $(47.08 \%)$ for the treatment $\left(\mathrm{V}_{2} \times \mathrm{T}_{2}\right)$. The lowest harvest index $(44.28 \%)$ for the treatment $\left(\mathrm{V}_{1} \times \mathrm{T}_{1}\right)$. Interaction effect of the variety and the treatments were found insignificant either at the $1 \%$ or $5 \%$ level of significant.

Table 3. Mean Effect of the interaction Between Varieties and Irrigation Treatments on the Yield and Yield Contributing Characters of BRRI dhan29 (V ${ }_{1}$ ) and BRRI hybrid2 $\left(V_{2}\right)$

\begin{tabular}{|c|c|c|c|c|c|c|c|c|c|c|c|c|}
\hline & $\begin{array}{l}\text { Plant } \\
\text { height } \\
(\mathrm{cm})\end{array}$ & $\begin{array}{l}\text { Total } \\
\text { tiller } \\
\text { Hill }^{-1}\end{array}$ & $\begin{array}{l}\text { Effective } \\
\text { tiller } \\
\text { Hill }^{-1}\end{array}$ & $\begin{array}{l}\text { Non-effective } \\
{\text { tiller } \text { Hill }^{-1}}\end{array}$ & $\begin{array}{l}\text { Panicle } \\
\text { length } \\
(\mathrm{cm})\end{array}$ & $\begin{array}{l}\text { Filled } \\
\text { grain } \\
\text { panicle }^{-1}\end{array}$ & $\begin{array}{l}\text { Unfilled } \\
\text { grain } \\
\text { panicle }^{-1}\end{array}$ & 1000-GW & $\begin{array}{l}\text { Grain } \\
\text { yield } \\
\left(\mathrm{t} / \mathbf{h a}^{-1}\right)\end{array}$ & $\begin{array}{l}\text { Straw } \\
\text { yield } \\
(\mathrm{t} / \\
\left.\mathrm{ha}^{-1}\right)\end{array}$ & $\begin{array}{l}\text { Biological } \\
\text { yield }\end{array}$ & $\begin{array}{l}\text { Harvest } \\
\text { Index }\end{array}$ \\
\hline $\mathrm{V}_{1} \mathrm{~T}_{1}$ & $99.85 c$ & 10.23 & 7.86 & 2.37 & 22.98 & $95.50 \mathrm{e}$ & $27.31 \mathrm{a}$ & 22.83 & $4.18 d$ & $5.26 \mathrm{e}$ & $9.44 \mathrm{e}$ & 44.28 \\
\hline $\mathrm{V}_{1} \mathrm{~T}_{2}$ & $101.32 \mathrm{c}$ & 11.95 & 11.04 & 0.91 & 23.92 & $138.22 b$ & $17.88 \mathrm{~d}$ & 24.16 & $5.10 \mathrm{c}$ & $6.08 c$ & $11.18 \mathrm{~cd}$ & 45.59 \\
\hline $\mathrm{V}_{1} \mathrm{~T}_{3}$ & $99.93 \mathrm{c}$ & 10.47 & 8.37 & 2.10 & 21.57 & $118.17 d$ & $22.06 \mathrm{c}$ & 23.02 & $5.08 \mathrm{c}$ & $5.75 d$ & $10.83 d$ & 46.93 \\
\hline $\mathrm{V}_{1} \mathrm{~T}_{4}$ & $106.72 \mathrm{ab}$ & 9.86 & 7.44 & 2.42 & 23.23 & $121.93 \mathrm{~cd}$ & $23.32 \mathrm{c}$ & 23.38 & $5.33 c$ & $6.23 c$ & $11.57 \mathrm{c}$ & 46.11 \\
\hline $\mathrm{V}_{2} \mathrm{~T}_{1}$ & $107.02 \mathrm{ab}$ & 10.56 & 8.27 & 2.30 & 23.85 & $143.13 \mathrm{ab}$ & $26.29 \mathrm{ab}$ & 23.31 & $5.24 \mathrm{c}$ & $6.97 \mathrm{a}$ & $12.21 \mathrm{~b}$ & 42.93 \\
\hline $\mathrm{V}_{2} \mathrm{~T}_{2}$ & $109.17 \mathrm{a}$ & 12.32 & 11.07 & 1.25 & 21.87 & $145.65 \mathrm{a}$ & $10.27 \mathrm{e}$ & 24.80 & $6.28 \mathrm{a}$ & $7.06 \mathrm{a}$ & $13.33 \mathrm{a}$ & 47.08 \\
\hline $\mathrm{V}_{2} \mathrm{~T}_{3}$ & $106.98 \mathrm{ab}$ & 11.24 & 8.97 & 2.27 & 21.87 & $136.58 b$ & $24.02 b c$ & 22.80 & $5.82 \mathrm{~b}$ & $6.57 \mathrm{~b}$ & $12.39 \mathrm{~b}$ & 46.99 \\
\hline $\mathrm{V}_{2} \mathrm{~T}_{4}$ & $104.84 b$ & 9.70 & 8.12 & 1.58 & 23.63 & $125.20 \mathrm{c}$ & $21.39 \mathrm{c}$ & 23.67 & $5.21 \mathrm{c}$ & $6.21 \mathrm{c}$ & $11.41 \mathrm{c}$ & 45.62 \\
\hline LSD & 1.48 & 0.42 & 0.29 & 0.37 & 1.39 & 3.70 & 1.41 & 0.70 & 0.19 & 0.19 & 0.26 & 1.27 \\
\hline $\begin{array}{l}\text { Level } \\
\text { of sig }\end{array}$ & $* *$ & NS & NS & NS & NS & $* *$ & $* *$ & NS & $* *$ & $* *$ & $* *$ & NS \\
\hline
\end{tabular}

In a column figures with same letter or without letter do not differ significantly whereas figures with dissimilar letter differ significantly (as per DMRT), * Significant at $5 \%$ level of probability, $* *=$ Significant at $1 \%$ level of probability, NS = Not significant

\subsection{Irrigation Treatments (AWDI)}

Irrigation treatments were applied at different stages of the growing period depending on the depletion of the water level in the perforated pipe. The very first treatment stated at the end of the fourth week after transplantation. During this time $5 \mathrm{~cm}$ standing water was kept to avoid weed infestation in the plots. Table 4 shows that the highest number of irrigation (14 nos.) was given to the plots with treatment $\mathrm{T}_{1}$ (continuous flooding) for BRRI dhan29. The other three treatments viz., $\mathrm{T}_{2}, \mathrm{~T}_{3}$ and $\mathrm{T}_{4}$ received a total of 9,8 and 7 nos. of irrigation for BRRI dhan 29 while 12, 9, 8 and 7 number of irrigation for BRRI hybrid2, respectively. Water 
required for crop establishment and water received from the rainfall was estimated to be $53.3 \mathrm{~cm}$ during the growing period for each of the treatments. For BRRI hybrid2, maximum amount of water $(112.20 \mathrm{~cm})$ was required for $\mathrm{T}_{1}$, while, second maximum $(91.20 \mathrm{~cm})$ for $\mathrm{T}_{2}$ was followed by other two treatments, $\mathrm{T}_{3}(87.20 \mathrm{~cm})$ and $\mathrm{T}_{4}(81.20 \mathrm{~cm})$. For BRRI dhan 29 the treatments $\mathrm{T}_{1}, \mathrm{~T}_{2}, \mathrm{~T}_{3}$ and $\mathrm{T}_{4}$ required 122.2, 97.2, 92.2 and $87.2 \mathrm{~cm}$ of water, respectively.

Table 4. Total Number of Irrigation Required for Different Irrigation Treatments.

\begin{tabular}{llllll}
\hline \multirow{2}{*}{ Treatment } & \multicolumn{2}{l}{ *No. of Irrigation } & \multirow{2}{*}{ Rainfall+ water for crop established (cm) } & \multicolumn{2}{c}{ Total water required (cm) } \\
& BRRI dhan 29 & BRRI hybrid2 \\
\hline $\mathrm{T}_{1}$ & 14 & 12 & 55.3 & 122.2 & 112.20 \\
$\mathrm{~T}_{2}$ & 9 & 9 & 55.3 & 97.20 & 91.20 \\
$\mathrm{~T}_{3}$ & 8 & 8 & 55.3 & 92.20 & 87.20 \\
$\mathrm{~T}_{4}$ & 7 & 7 & 55.3 & 87.20 & 81.20 \\
\hline
\end{tabular}

*One irrigation means application of $5 \mathrm{~cm}$ irrigation water

The graphical representation of water usage by different treatments after transplantation is shown in Fig.1

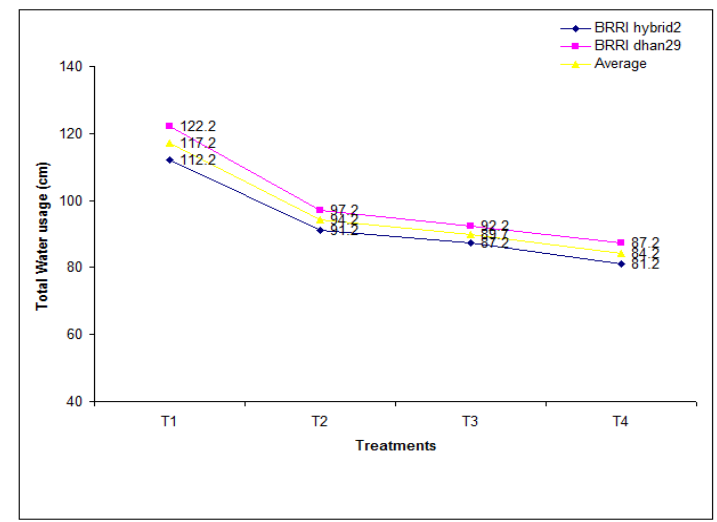

Fig 1. Water usage of different treatments for the production of BRRIdahn29 and BRRI hybrid2.

\subsection{Water Use Efficiency}

Water use efficiencies for the individual effect of different treatments were derived along with the values of WUE for the 8 interactions between treatments and varieties (Table 5). The highest water use efficiency, WUE was found to be $87.38 \mathrm{~kg} / \mathrm{ha} / \mathrm{cm}\left(\mathrm{V}_{1} \times \mathrm{T}_{2}\right)$. All the highest water use efficiencies were found in the combinations having variety $\mathrm{V}_{1}$ (BRRIdhan29). The lowest WUE was obtained in the treatment $T_{1}$ for $V_{2}$. In case of BRRIdhan $29\left(\mathrm{~V}_{1}\right)$ the highest WU was found to be $87.38 \mathrm{~kg} / \mathrm{ha} / \mathrm{cm}$ of water and the lowest was found to be $86.11 \mathrm{~kg} / \mathrm{ha} / \mathrm{cm}$. The second highest WUE highest WUE $(87.38 \mathrm{~kg} / \mathrm{ha} / \mathrm{cm})$ was found in the treatment $\mathrm{T}_{2}$ though it gave poor yield $(5.10 \mathrm{t} / \mathrm{ha})$. Treatment $\mathrm{T}_{2}$ gave high yield with high water use efficiency $(85.55 \mathrm{~kg} / \mathrm{ha} / \mathrm{cm})$ among the others (Table 5).

Table 5. Water use Efficiency for Different Treatments and Interactions.

\begin{tabular}{|c|c|c|c|c|c|c|c|c|c|}
\hline Interactions & $\begin{array}{l}\text { Total } \\
\text { water } \\
\text { required } \\
(\mathrm{cm}) \\
\end{array}$ & $\begin{array}{l}\text { Water } \\
\text { applied } \\
(\mathrm{cm})\end{array}$ & $\begin{array}{l}\text { Grain } \\
\text { Yield } \\
\text { (t/ha) }\end{array}$ & $\begin{array}{l}\text { Water use } \\
\text { efficiency } \\
(\mathrm{kg} / \mathrm{ha} / \mathrm{cm})\end{array}$ & Treatments & $\begin{array}{l}\text { Average } \\
\text { total water } \\
\text { required } \\
(\mathrm{cm}) \\
\end{array}$ & $\begin{array}{l}\text { Average } \\
\text { grain yield } \\
\text { (t/ha) }\end{array}$ & $\begin{array}{l}\text { Water } \\
\text { use } \\
\text { efficiency } \\
\mathrm{kg} / \mathrm{ha} / \mathrm{cm} \text { ) } \\
\end{array}$ & $\begin{array}{l}\text { Water } \\
\text { productivity } \\
\text { (t/ha/cm) }\end{array}$ \\
\hline $\mathrm{V}_{1} \mathrm{~T}_{1}$ & 118.69 & 137.83 & 4.18 & 86.11 & \multirow{2}{*}{$\mathrm{T}_{1}$} & \multirow{2}{*}{116.25} & \multirow{2}{*}{4.71} & \multirow{2}{*}{84.34} & 0.029 \\
\hline $\mathrm{V}_{1} \mathrm{~T}_{2}$ & 116.08 & 132.83 & 5.10 & 87.38 & & & & & 0.037 \\
\hline $\mathrm{V}_{1} \mathrm{~T}_{3}$ & 115.55 & 133.33 & 5.08 & 86.66 & \multirow{2}{*}{$\mathrm{T}_{2}$} & \multirow{2}{*}{113.64} & \multirow{2}{*}{5.69} & \multirow{2}{*}{85.55} & 0.037 \\
\hline $\mathrm{V}_{1} \mathrm{~T}_{4}$ & 115.55 & 130.33 & 5.33 & 86.66 & & & & & 0.039 \\
\hline $\mathrm{V}_{2} \mathrm{~T}_{1}$ & 113.82 & 137.83 & 5.24 & 82.57 & \multirow{2}{*}{$\mathrm{T}_{3}$} & \multirow{2}{*}{113.11} & \multirow{2}{*}{5.45} & \multirow{2}{*}{84.83} & 0.037 \\
\hline $\mathrm{V}_{2} \mathrm{~T}_{2}$ & 111.21 & 131.83 & 6.28 & 84.31 & & & & & 0.046 \\
\hline $\mathrm{V}_{2} \mathrm{~T}_{3}$ & 110.68 & 131.33 & 5.82 & 84.27 & \multirow{2}{*}{$\mathrm{T}_{4}$} & \multirow{2}{*}{113.11} & \multirow{2}{*}{5.27} & \multirow{2}{*}{85.79} & 0.043 \\
\hline $\mathrm{V}_{2} \mathrm{~T}_{4}$ & 110.68 & 131.33 & 5.21 & 84.27 & & & & & 0.038 \\
\hline
\end{tabular}

Water productivity was found to be the highest $(0.046$ $\mathrm{t} / \mathrm{ha} / \mathrm{cm}$ ) in treatment $\mathrm{T}_{2}$ (irrigation when water is $15 \mathrm{~cm}$ below the soil surface) followed by treatment $\mathrm{T}_{3}$ $(0.043 \mathrm{t} / \mathrm{ha} / \mathrm{cm})$ (irrigation when water is $20 \mathrm{~cm}$ below the soil surface) and a minimum of $0.029 \mathrm{t} / \mathrm{ha} / \mathrm{cm}$ treatment $\mathrm{T}_{1}$ (continuous flooding). From these results, it can be seen that the water productivity decreased with the increase of irrigation water.

The observed effects of AWDI on rice cultivation are in agreement with Prior research. Numerous studies focused on manipulating the depth and interval of irrigation water have reported that continuous standing water of rice during cultivation is not essential for obtaining high yields. [11],
[12], [13] reported that maintaining a very thin water layer, at saturated soil condition, or alternate wetting and drying can reduce water applied to the field by about 40-70 percent compared with the traditional practice of continuous shallow submergence, without a significant yield loss. A similar result was obtained by [14] concluded that a standing depth of water throughout the season is not needed for high rice yields. They added that about $40-45$ percent of the water normally used in irrigating the rice crop in the dry season was saved by applying water in small quantities only to keep the soil saturated throughout the growing season, without sacrificing rice yields. [15] reported increased water productivity $\left(1.26 \mathrm{~kg} / \mathrm{m}^{3}\right)$ in AWDI plot at $9 \mathrm{~cm}$ ponding 
depth compared to continuous flooding $\left(0.96 \mathrm{~kg} / \mathrm{m}^{3}\right)$. [16], [17] concluded that in Southern China, AWDI for rice should be more widely used because of its potential to conserve water (20-35\% reduction in water use), increase water productivity (from $0.65-0.82 \mathrm{~kg} / \mathrm{m}^{3}$ to $1.18-1.50 \mathrm{~kg} / \mathrm{m}^{3}$ after the application of AWDI), increase rice yield (15-28\%), and potential to improve the root environment (i.e., soil oxygen content increased by $120-200 \%)$. [18], [19] also reported a reduced irrigation water requirement for non-flooded rice by 20-50 percent than for flooded rice, with the difference strongly dependent on soil type, rainfall, and water management practices. [19], however, reported a decrease in rice yields under non-flooded conditions that was proportional to the level of water stress experienced by the plants. There is a concern that the AWDI method of water management promotes greater weed populations, thus requiring more labor for weed management. Association-[20], [21] reported that SRI methodology required approximately 38-54\% more labor than conventional methods. According to [22], $62 \%$ of the extra labor was needed for weed management while $17 \%$ was for transplanting. Alternate drying and wetting of the fields allows for good aeration of the soil and better root growth thereby increasing rice yield and water use efficiency [22]. However, the efficient use of water is the most controversial component in rice farming and also one of the most difficult aspects for farmers to master. In order to achieve the necessary control of water levels, farmers must have a level field and a functioning irrigation system that allows for the precise control of the inflow and outflow of any individual field.

Experiments and field survey of the AWDI method of cultivating rice from different parts of the world have demonstrated the utility of AWDI for water saving in irrigated rice cultivation. This experiment also indicated that Water Productivity Index increased and that land productivity (i.e., yield per unit of land) did not differ from conventionally standing water. This field experiment confirms that AWDI is a sustainable method in irrigated rice cultivation with benefits on water saving and maintaining the productivity comparable to conventional standing water.

The increased productivity of water and its resource saving aspects are likely to be the vital factors that will make farmers and other stakeholders adopt AWDI in water-scarce areas. However, it is difficult to make general conclusions as AWDI methods adopted in a certain area may not transfer to other areas because of variability in topography, soil, and climatic conditions across the rice agro-ecological zones. Therefore, it is important that comparative studies be conducted in different environments to verify this practice as a way to save water under conditions of water scarcity while maintaining, or increasing, crop yields.

\section{Recommendation}

In order to achieve a large-scale spread and adoption of AWD, at least in regions where water scarcity poses a threat to sustain and further improve rice cultivation, a number of constraints and issues at national, regional and local levels have to be overcome as suggested by the findings.

Since the further spread of AWD at this stage depends to a great extent on the actions taken and efforts made at the organizational level to improve and institutionalize the dissemination process in Bangladesh.

Lastly, the study offers some general recommendations and lessons for disseminating natural resource management technologies, based on experiences in Bangladesh, which are specific to the dissemination of AWD technology. AWD dissemination should become a priority/vital issue on the agenda of the National Agricultural Technology Coordination Committee (NATCC), formulate a national Plan of Action of AWD dissemination in Bangladesh, develop strategic partnerships for disseminating AWD, including local government representatives in local processes of AWD dissemination will help to further promote the technology among farmers, design training to fit AWD use in command areas of irrigation systems, improve monitoring and evaluation of AWD dissemination.

\section{Acknowledgements}

The authors greatly acknowledge Asian Development Bank-Japan Scholarships Program (ADB-JSP) for funding support. Sincere thanks are due to the laboratory members of agro-environmental engineering (AEE) and collaborating farmer in Kashiwa, Chiba, Japan for their active support and cooperation throughout the field experiment.

\section{References}

[1] S.I. Bhuiyan, "Water management in relation to crop production: Case study on rice" Outlook on Agriculture. 1992. vol. 21, pp293-299.

[2] P.K. Sharma, "Effect of Period Moisture Stress on Water-use Efficiency in Wetland Rice" Oryza, 1989, vol. 26, pp252-257.

[3] W.D. Ruckelshaus, "Toward a sustainable world" Scientific American, 1989 vol. 261,3, pp.114 - 120

[4] Government of Western Australia, "Hope for the Future: The Western Australian State Sustainability Strategy". Department of the Premier and Cabinet, Perth, Western Australia, 2003.

[5] P. Rogers, K.F., Jalal and J.A. Boyd, "An Introduction to Sustainable Development, 2nd Ed., 2000, Earthscan, London, UK.

[6] L. Feng, B.A.M. Bouman, T.P. Tuong, R.J. Cabangon, Y. Li, G. Lu and Y. Feng "Exploring options to grow rice using less water in northern China using a modelling approach: I. Field experiments and model evaluation" Agricultural Water Management, 2007, Vol. 88, Issues 1-3, 16 March 2007, pp.1-13 
[7] B.A.M. Bouman, L. Feng and T.P. Tuong, G.L.H. Wang and Y. Feng, "Exploring options to grow rice under water-short conditions in northern China using a modeling approach. II: Quantifying yield, water balance components, and water productivity" Agricultural Water Management 2007, vol. 88, pp.23-33.

[8] A.M. Shamsuddin, M.A. Islam and A. Hossain, "Comparative Studies on the Yield and Agronomic characters of nine Cultivars of Aus Rice" Bangladesh J. Agril. Sci., 1988 vol. 15,1 pp. 121-124.

[9] M.J.U. Chowdhury, A.U. Sarker, M.A.R. Sarker and M.A. Kashem, "Effect of variety and number of seedling hill ${ }^{-1}$ on the yield and its components on late transplanted aman rice" Bangladesh J. Agric. Sci., 1993, vol. 20, pp. 311-316.

[10] M.A. Hassan, M.A. Salam and M.R. Arsan, "Influence of certain factors on severity of stalk rot disease of grain sorghum in Upper Egypt. Aust J Agric Sci. 1996; vol. 27, 179-189.

[11] S. Hatta, Water consumption in paddy field and water saving rice culture in the tropical zone. Japan Journal of Tropical Agriculture, 1967, vol.11, pp. 106-112.

[12] D.F. Tabbal, R.M. Lampayan, and S.I. Bhuiyan, "Water-efficient irrigation technique for rice. In V. V. N. Murty, \& K. Koga (Eds.), Soil and water engineering for paddy field management" Proceedings of the International Workshop on Soil and Water Engineering for Paddy Field Management, 1992, 28-30 January. Bangkok, Thailand: Asian Institute of Technology.

[13] C.B. Singh, T.S. Aujla, B.S. Sandhu, and K.L. Khera, "Effects of transplanting data and irrigation regime on growth, yield and water use in rice (Oryza sativa) in northern India" Indian Journal of Agricultural Sciences, 1996, vol. 66, pp.137-141.

[14] S.I. Bhuiyan and T.P. Tuong, "Water use in rice production: Issues, research opportunities and policy implications. Paper presented at the Inter-Center Water Management Workshop", 29-30 September 1995.Colombo, Sri Lanka: International Irrigation Management Institute. Geneva: 1996, World Health Organization.
[15] V. Anbumozhi, E. Yamaji and T. Tabuchi, "Rice crop growth and yield as influenced by changes in ponding water depth, water regime and fertigation level" Agricultural Water Management, 1998, 37, 241- 253. doi:10.1016/S0378-3774(98)00041-9, http://dx.doi.org/10.1016/S0378-3774(98)00041-9

[16] Z. Mao, "Principle and technique of water saving irrigation for rice" Hubei Province, People's Republic of China: 1993 Wuhan University of Hydraulic and Electric Engineering.

[17] Z. Mao, "Environmental impact of water-saving irrigation for rice" In Irrigation scheduling: From theory to practice. Proceedings of the ICID/FAO Workshop on Irrigation Scheduling, Rome, Italy, 12-13 September 1995. Rome: FAO, 1996.

[18] S. Keisuke, E. Yamaji, S. Sato, P.S. Budhiharto and M. Mizoguchi, "Sustainability of System of Rice Intensification: Benefits of SRI focusing on effects of intermittent irrigation on yield increase and water savings" In: Proceeding of PAWEES 2007 6th International Conference on Sustainable Rural Development and Management 18 October 2007. South Korea: Seoul National University, pp. 25-37.

[19] G. Davids "Use of the Capital Intensive Irrigation Systems in Rice" Davids Engineering, 1998 Inc. California, USA.

[20] Association-Tefy-Saina, "Couts de Revient Dans les Systmes de Riziculture Divers" Association Tefy Saina, 1995, National Workshop on SRI, Antananarivo.

[21] H.W. Rakotomalala, "Comparison entre la Rizicullture Traditionnelle et le Systeme de Riziculture Intensive dans La Region de Ranomafana Science Agronomique" Antananarivo: Universite d'Antananarivo. September 2011 ISSN 1916-9752 E-ISSN 1916-9760, Journal of Agricultural Science, 1997, .vol. 3, 3.

[22] N. Uphoff, "The System of Rice Intensification (SRI) as a methodology for reducing water requirements in irrigated rice production. Paper for International Dialogue on Rice and Water: Exploring Options for Food Security and Sustainable Environments" held at IRRI, 7-8 March 2006, Los Baños, Philippines. 